BLS 32, No 2 2006. DOI: http://dx.doi.org/10.3765/bls.v32i2.3495

(published by the Berkeley Linguistics Society and the Linguistic Society of America)

\title{
Apical Obstruents in Pre-Proto-Tangkic and the Origins of the Non-Zero Absolutive
}

\author{
ERICH R. ROUND \\ Yale University
}

\section{Introduction}

This paper presents an extract from a larger research project (Round, in prep.) aimed at reconstructing the history of nominal morphology in the non-PamaNyungan, Tangkic languages of Queensland, Australia. Below I follow one of the subplots that runs through the long-term evolution of the system, namely the disappearance and then reappearance of non-initial apical oral stops, [t] and [t]. The story of word-medial $[\mathrm{t}]$ is particularly interesting because its reappearance occurs during a sequence of events which culminates in the emergence of the young, non-zero Tangkic absolutive marker, a marker whose precise historical origins have proven elusive for a number of decades now.

After this introduction, the paper is arranged into three main sections. Section 1 outlines some of the key characteristics of the Tangkic languages; section 2 covers the early change in which original apical oral stops are lost from certain positions; and section 3 presents a new account of the emergence of the Tangkic absolutive marker, clarifying the circumstances which led up to it and explaining why the allomorphs which result are those given in (1).

(1) Stem-conditioned allomorphy of the Tangkic non-zero absolutive

$\begin{array}{llll}\text {-ja } & \text { after [i] } & \text { /-ka/ } & \text { after underlying velar C } \\ \text {-wa } & \text { after [u] } & \text { /-ta/ } & \text { after underlying coronal C } \\ \text {-.a } & \text { after [a] } & & \text { (but }[-\mathrm{a}] \text { after } / \mathrm{r} / \text { ) }\end{array}$

In existing speculations on the origins of this allomorphy, Evans (1995:138) and Blevins (1997) presume that $-t a$ and $-k a$ appeared first as part of an emergent vowel-final constraint on words, with the glide-initial allomorphs following later. The actual source of $-t a$ and $-k a$ has remained a mystery though. ${ }^{1}$ Below I provide

\footnotetext{
${ }^{1}$ One question is whether Tangkic $-t a$ and $-k a$ are comparable to the - $p a$ augments of languages such as Pitjantjatjara, Inggarda, and Warlpiri (see, e.g., Hale 1973). Here, Evans (1996:137) posits
} 
a source for all of the allomorphs in (1) and offer a revised hypothesis concerning their relative order of appearance.

\section{An Overview of the Tangkic Languages}

(2) presents the postulated genetic tree for the Tangkic-Minkin family (see Evans 1980, 1995:9-13). ${ }^{2}$ Most of the changes discussed in this paper are restricted to Tangkic proper.

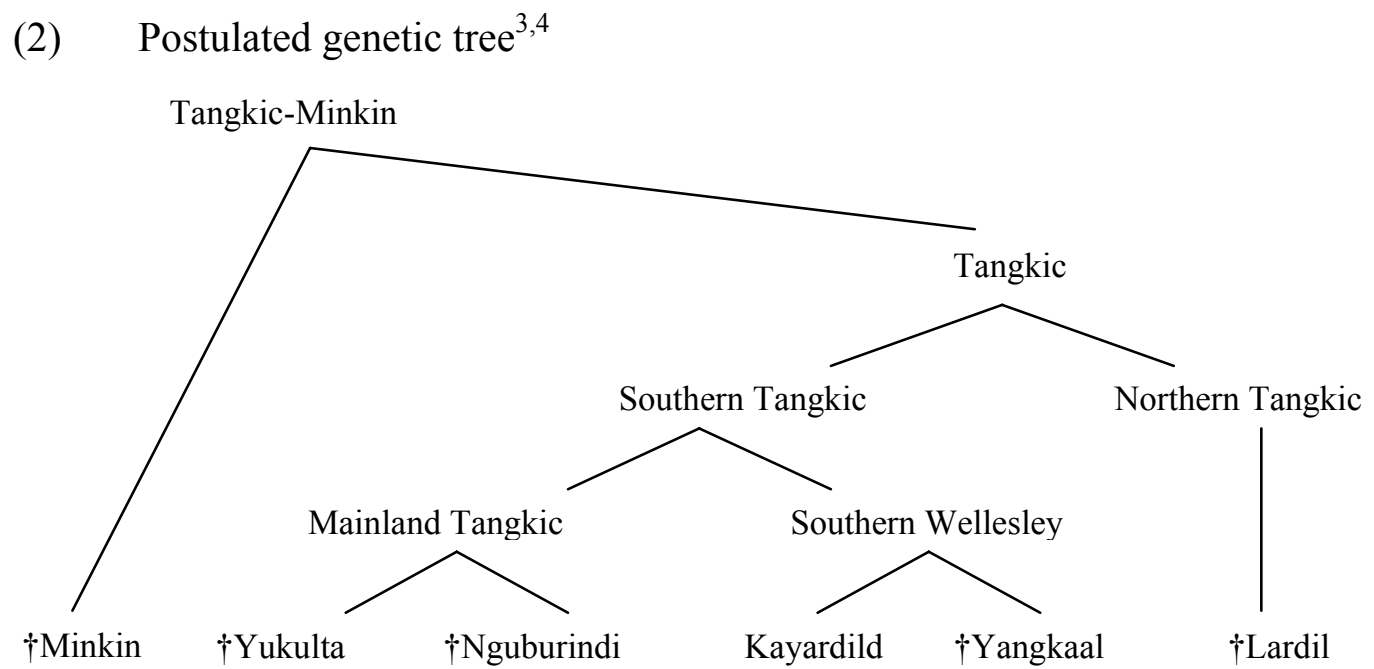

Given in (3), the phonemic inventory varies only marginally during the reconstructed history of Tangkic-Minkin. The main features are all unexceptional in the Australian context: there are six places of articulation (four coronal; velar; and labial); coronal places divide into natural classes defined by the active articulator

an erstwhile discourse particle $=p a$ which became an obligatory augment to originally consonantfinal words (and thence part of the stem in Warlpiri), and suggests that Tankgic -ta/-ka/-ja/-wa/-øa may have had similar roots (as $*=k a>* w a / \mathrm{V}_{-}$; then place assimilation). The main problem facing this analysis is its implication for laminal finals, that $* c=k a$ and $* t=k a>t a$, which is not derivable by assimilation. Now, one could suppose that there were in fact two original clitics, $*=k a$ and $*=t a$, but although a focus clitic $=k a$ does exist in modern Tangkic, there is no attested $=t a$, and worse, one does find $=t a$, in which case, given the general homorganic conditioning of the absolutive allomorphs, it is odd that it should have been $*=t a$ and not $*=t a$ which attached to laminal finals. The present account avoids these problems.

${ }^{2}$ Principal references: Minkin (Evans 1980), Yukulta (Keen 1983), Nguburindi - a word list (Roth 1897), Kayardild and Yangkaal (Evans 1992, 1996), Lardil (Hale 1967, 1975; Klokeid 1976; Ngakulmungan Kangka Leman 1997).

${ }^{3}$ While Minkin has been viewed as related to Tangkic since Evans (1980), the label TangkicMinkin is proposed here for the first time.

${ }^{4}$ The Southern Tangkic subgroup has not been rigorously established, but is posited on the basis of lexicostatistics and the fact that only Lardil developed extensive phonological truncation processes. Since the latter observation bases the subgroup on shared retentions rather than shared innovations, a definitive subgrouping of Tangkic remains a task for future research. 


\section{Pre-Proto-Tangkic Apicals and the Absolutive}

(apical versus laminal); there is no contrastive voicing, and nasal stops appear at all six places of articulation; and there are three glides, two laterals (both phonemically apical), and a trill. Minor variations are listed at the bottom of (3).

\begin{tabular}{|c|c|c|c|c|c|c|}
\hline & \multicolumn{2}{|c|}{ apico- } & \multicolumn{2}{|c|}{ lamino- } & \multirow[b]{2}{*}{ velar } & \multirow[b]{2}{*}{ labial } \\
\hline & alveolar & $\begin{array}{c}\text { post- } \\
\text { alveolar }\end{array}$ & dental & palatal & & \\
\hline $\begin{array}{l}\text { obstruent } \\
\text { nasal } \\
\text { trill } \\
\text { lateral } \\
\text { glide }\end{array}$ & $\begin{array}{l}\mathrm{t} \\
\mathrm{n} \\
\mathrm{r} \\
1\end{array}$ & $\begin{array}{l}t \\
\eta \\
l \\
l\end{array}$ & $\begin{array}{l}\mathrm{t} \\
\mathrm{n} \\
\mathrm{n}\end{array}$ & $\begin{array}{l}\mathrm{c} \\
\mathrm{n}\end{array}$ & $\begin{array}{l}\mathrm{k} \\
\mathrm{y}\end{array}$ & $\begin{array}{l}\mathrm{p} \\
\mathrm{m}\end{array}$ \\
\hline vowels & \multirow{2}{*}{\multicolumn{6}{|c|}{$\begin{array}{l}\text { Minor variations: } \\
\text { a. possible original } * / 1 /, * / K / \text { collapse with } / / /, / / \\
\text { b. late merger of } / / / \text { and } / / / \text { in Lardil and Kayardild } \\
\text { c. long vowels may at one point have been absent } \\
\text { d. late development in Lardil of /e/, /e:/ } \\
\text { e. on distributional grounds, it could be said that } / \mathrm{t} / \text { and } \\
/ \mathrm{r} / \text { merged for a short period }\end{array}$}} \\
\hline $\begin{array}{c}\mathrm{i}, \mathrm{i}: \quad \mathrm{u}, \mathrm{u} \\
\mathrm{a}, \mathrm{a}:\end{array}$ & & & & & & \\
\hline
\end{tabular}

Turning from the underlying inventory to the phonological constraints operating in the languages, the most important are as follows.

Formulated by Hamilton (1989), HAMILTON'S GENERALIZATION states that for any consonant cluster, the sequence of segments is strictly ordered: apicals are first, followed by laminals, then velars, and then labials, cf. (4a). This constraint is found in many Australian languages; it is unviolated in all the of modern Tangkic languages, and there is no reason to reconstruct any period at which this was not also the case.

There are two corollaries of Hamilton's generalization which are relevant in this paper. The first is that deletions, whether seen as diachronic correspondences or synchronic processes, fall into the natural classes given in (4b). Consequent to the first is the second, long-term diachronic corollary-that inventories of phonotactically attested or permissible final consonants (whether word-final or stemfinal) also fall into natural classes, given in (4c).

Hamilton's generalization (Hamilton 1989) and its corollaries
a. Order must be:
Apical $>$ Laminal $>$ Velar $>$ Labial
b. Immediate corollary:
Natural classes of deletions:

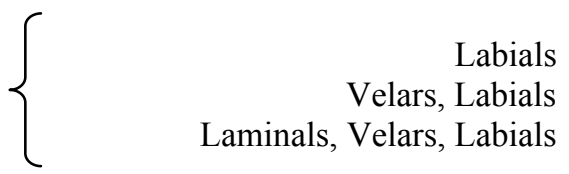


c. Long-term diachronic corollary / Typological generalization:

Most common inventories of stem- \& word-final consonants:

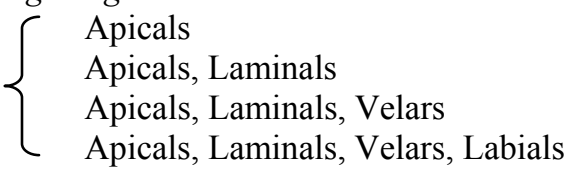

The only other constraints which will concern us here are given in $(5 a, b)$ : there are no geminates, no glides in codas, and no reason for reconstructing them. The constraints are satisfied as in $(5 \mathrm{c})$.

(5) Other key constraints
a. *Geminate:
$/ \mathrm{C}_{\alpha}+\mathrm{C}_{\alpha} />\left[\mathrm{C}_{\alpha}\right]$
b. Ordering by manner/sonority
$\left.\begin{array}{ll}\text { Order must be: } & \text { Liquid / Nasal }>\text { Glide } \\ & \text { Liquid }>\text { Nasal }>\text { Obs }\end{array}\right\} \therefore$ no glides in codas
c. Satisfaction of constraints
Achieved by: i. regressive assimilation of $\mathrm{Nasal}+\mathrm{Obs}$
ii. deletion of $C$ from right-edge of morpheme $M_{1}$ in $/ M_{1}+M_{2} /$

Turning to morphology, what we are concerned with here are nominals, a part of speech in Tangkic that covers roughly the same functional range as English nouns and adjectives. In (6) I list the morphological environments in which one finds nominal stems in Tangkic. I will refer below particularly to nominal and verbal compounds. Nominal compounds (6c) are right-headed except if they end in the morpheme tayka (the root from which Tangkic draws its name). In verbal compounds, a nominal stem precedes a verbal stem (6d).

(6) Morphological distribution of nominal stems
a. Simple inflected stems: STEM $_{\mathrm{N}}-\mathrm{INFL}$
b. Case stacking:
$\left[\right.$ STEM $_{\mathrm{N}}$-INFL]-INFL... e.g. Kayardild [[tayka-kara]-yuni]-nca
[[man-GEN]-INSTR]-OBL

c. Nominal compounds

\begin{tabular}{|c|c|c|c|c|c|}
\hline \multirow[t]{3}{*}{ i. } & $\mathrm{N}_{\mathrm{HEAD}}+\mathrm{N}$ & e.g. & Kayardild & $\begin{array}{l}\text { may-cuyara } \\
\text { hand-big }\end{array}$ & 'big handed' \\
\hline & & & Yukulta & $\begin{array}{l}\text { mankar-patayu } \\
\text { body-big }\end{array}$ & 'well built' \\
\hline & & & Lardil & $\begin{array}{l}\text { /mil-kitikitil } \\
\text { edge-moon }\end{array}$ & 'halo around moon' \\
\hline \multirow[t]{2}{*}{ ii. } & $\mathrm{N}+\mid$ tanka $\left.\right|_{\mathrm{HEAD}}$ & e.g. & Kayardild & kunpa-tanka & 'person from Kunba' \\
\hline & & & Lardil & $\begin{array}{l}\text { Inulma-taykal } \\
\text { restricted-person }\end{array}$ & 'avoided person' \\
\hline
\end{tabular}




\section{Pre-Proto-Tangkic Apicals and the Absolutive}

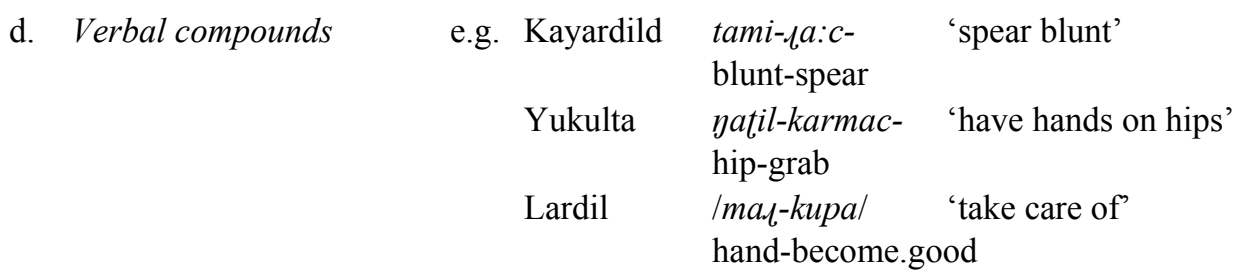

To complete the overview of Tangkic, the final phenomenon of direct relevance to the reconstruction below is Tangkic 'truncation' (Hale 1973). Although the synchronic process of truncation is most famously known from Lardil, it can also be understood as a general Tangkic characteristic involving: (i) deletion of a final vowel, and (ii) the consequent deletion of phonotactically banned final consonants. The parameters for the modern languages are given in (7a), and what I reconstruct for Proto-Tangkic in (7b); note that all of the modern languages have simplified the ancestral system in some way, whether by restricting it or generalizing. I will be proposing below that the young Tangkic absolutive marker emerged during a series of reanalyses of this system, including rule inversion.

Tangkic truncation and its parameters

a.

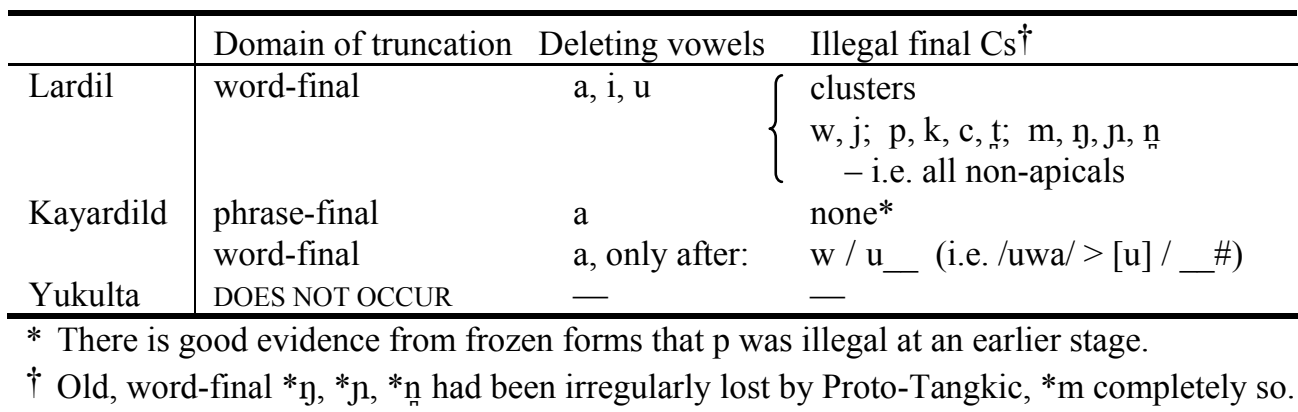

Proposal:

b.

\begin{tabular}{|c|c|c|}
\hline $\begin{array}{l}\text { Proto- } \\
\text { Tangkic }\end{array}$ & $\begin{array}{l}\text { phrase-final (obligatory } \\
\text { word-final (optional) }\end{array}$ & onals \\
\hline
\end{tabular}

\section{The Early Loss of Final Apical Stops from Tangkic Nominal Stems}

Apical oral stops are synchronically absent from the final position in Tangkic nominal stems, and I propose this absence is due to historical loss at an early stage. This presupposes that modern Tangkic languages do in fact lack stem final $/ \mathrm{t} /$ and $/ t /$; hence, I address first some early analyses of Lardil and Yukulta in which this was not taken to be the case.

All modern Tangkic languages have stems whose absolutive (or nominative) $)^{5}$ form ends in [ta] and whose other case inflections end in some laminal plus other

\footnotetext{
${ }^{5}$ The nominative case of Lardil and Kayardild is cognate with the Yukulta absolutive, and all derive from the earlier Proto-Tangkic absolutive (Evans 1996:423ff).
} 
material, as illustrated in (8). The original analyses for both Lardil and Yukulta were that these stems underlyingly end in apical stops which undergo a process of 'laminalization' outside of the absolutive/nominative. The underlying-apical analysis of Lardil, Yukulta

\begin{tabular}{|c|c|c|c|c|}
\hline \multirow[b]{2}{*}{ Lardil } & & & \multirow{2}{*}{$\begin{array}{l}\text { NOM } \\
\text { nuta } \\
\text { /nut }+ \text { a/ }\end{array}$} & FUTURE.OBJ \\
\hline & & $\begin{array}{l}\text { /nut/ /nit/ } \\
\text { 'firewood' }\end{array}$ & & $\begin{array}{l}\text { nौc-e } \\
/ \text { nit }+ \text { e/ }\end{array} \quad \begin{array}{l}\text { nit-u. } \\
/ \text { nit }+ \text { u.ju/ }\end{array}$ \\
\hline & b. & $\begin{array}{l}/ \mathrm{pit} / \\
\text { 'smell' }\end{array}$ & $\begin{array}{l}\text { pita } \\
/ \text { pit }+\mathrm{a} /\end{array}$ & $\begin{array}{ll}\text { pic-e } & \text { pit-ut } \\
/ \text { pit }+ \text { e/ } & / \text { pit }+ \text { u. u } /\end{array}$ \\
\hline & & & & laminalization: $/ \mathrm{t} />[\mathrm{c}] / \_\mathrm{i}, \mathrm{e} ; \quad>[\mathrm{t}] / \_\mathrm{a}, \mathrm{u}$ \\
\hline
\end{tabular}

\begin{tabular}{|c|c|c|c|c|c|}
\hline \multirow{6}{*}{ Yukulta } & & & \multirow{3}{*}{$\begin{array}{l}\text { ABS } \\
\text { yita } \\
/ \text { yit }+\mathrm{a} /\end{array}$} & ERG/LOC & COMITATIVE \\
\hline & & /nit/ & & nic-iya & nic-ulu \\
\hline & & 'firewood' & & /nit + iya/ & $/$ nit + ulu/ \\
\hline & d. & /pit/ & pita & pit-iya & pit-ulu \\
\hline & & 'smell' & $/ p i t+a /$ & $/$ pit + iya/ & $/ p i t+u l u /$ \\
\hline & & & & $/ \mathrm{t} />[\mathrm{t}],[\mathrm{c}]$ idios & ically, dependent on stem \\
\hline
\end{tabular}

As indicated by the arrows in (8), the analysis holds water for Lardil because the laminal of any stem's non-nominative forms is predictable from the following vowel. In Yukulta, though, this is not the case: laminals are lexically idiosyncratic. A superior analysis by Evans (1995) is that for Yukulta, and also for Kayardild and proto-Tangkic, ${ }^{6}$ it is the laminal which is underlying (as in (9)). Evans replaces the laminalization process with de-laminalization; however, even this is not needed. By Hamilton's generalization, an underlying laminal + apical cluster undergoes deletion of the laminal: the alternation is predicted by the regular phonology of the languages.

\footnotetext{
${ }^{6}$ The underlying-apical analysis succeeds in Lardil because the two original stem-final laminals have collapsed, removing the lexical contrast. Even in Lardil, though, it seems possible to posit underlying laminals and derive 'delaminalization' from nominal /-ta/ and Hamilton's generalization (see also Hale 1973:437ff for the inconclusiveness of one argument from analytical elegance for underlying / $t /$; on Hale's appeal to facts in Damin, see further Round, in prep.).
} 


\section{Pre-Proto-Tangkic Apicals and the Absolutive}

(9) Evans's (1995) analysis [modified to incorporate Hamilton's generalization]

\begin{tabular}{|c|c|c|c|c|c|}
\hline \multirow[t]{2}{*}{ Lardil } & & $\begin{array}{l}\text { /nuc/ /nic/ } \\
\text { 'firewood' }\end{array}$ & $\begin{array}{l}\text { nuta } \\
\text { /nuc }+ \text { ta/ }\end{array}$ & $\begin{array}{l}\text { nic-e } \\
/ \text { jic }+\mathrm{e} /\end{array}$ & $\begin{array}{l}\text { nit-u. } \\
\text { /nic }+ \text { u.u/ }\end{array}$ \\
\hline & b. & $\begin{array}{l}\text { /pic/ } \\
\text { 'smell' }\end{array}$ & $\begin{array}{l}\text { pita } \\
/ \text { pic }+ \text { ta/ }\end{array}$ & $\begin{array}{l}\text { pic-e } \\
/ \text { pic }+ \text { e/ }\end{array}$ & $\begin{array}{l}\text { pit-ul } \\
/ \text { pic }+ \text { u.u } /\end{array}$ \\
\hline Yukulta & c. & $\begin{array}{l}\text { /yic/ } \\
\text { 'firewood' }\end{array}$ & $\begin{array}{l}\text { yita } \\
/ \text { yic }+ \text { ta/ }\end{array}$ & $\begin{array}{l}\text { yic-iya } \\
\text { /yic + iya/ }\end{array}$ & $\begin{array}{l}\text { yic-ulu } \\
/ \text { yic }+ \text { ulu/ }\end{array}$ \\
\hline & d. & $\begin{array}{l}\text { /pit/ } \\
\text { 'smell' }\end{array}$ & $\begin{array}{l}\text { pita } \\
/ \text { pit }+ \text { ta/ }\end{array}$ & $\begin{array}{l}\text { pit-iya } \\
\text { /pit + iya/ }\end{array}$ & $\begin{array}{l}\text { pit-ulu } \\
/ \text { pit }+ \text { ulu/ } /\end{array}$ \\
\hline
\end{tabular}

Admitting this analysis, the inventory of final consonants for nominal stems reconstructed for Proto-Tangkic is given in (10).

(10) Final consonants/clusters of nominal stems in Proto-Tangkic

\begin{tabular}{|l|cc:cc:c|}
\hline $\begin{array}{l}\text { obstruent } \\
\text { nasal } \\
\text { liquid } \\
\text { clusters }\end{array}$ & $\mathrm{n}$ & $\mathrm{n}$ & $\mathrm{t}$ & $\mathrm{c}$ & $\mathrm{k}$ \\
$\mathrm{r}, \mathrm{l}$ & $\mathrm{l}$ & & $\mathrm{y}$ \\
& & & & $\mathrm{rk}, \mathrm{k}, \mathrm{k} ; \mathrm{rg}, \mathrm{ln}$ \\
\hline
\end{tabular}

Note that in relation to the typologically normal inventories of final consonants given earlier in (4c), the Tangkic inventory exhibits gaps: it lacks apical oral stops, it lacks laminal nasals, and arguably non-velar final clusters. In this paper, I focus on the oral stops. ${ }^{7}$

Since we aim, all things equal, to reconstruct typologically regular protosystems over irregular ones, an obvious question is: can one find evidence that the stem-final apical oral stops were lost at some stage? The answer is yes.

In (11), I give the developments which removed original stem-final $/ \mathrm{t} /$ and $/ \mathrm{t} /$ from the system. None of these individual changes is particularly remarkable: apical stops flap after vowels; flaps fall together with trills if no vowel follows; and the remaining apico-alveolar (non-retroflex) flaps fall together with the trill.

\footnotetext{
${ }^{7}$ However, see (16) for some indication of how the disappearance of the laminal nasals is precipitated by the accretion of the - $t a$ absolutive suffix. The reconstructed history of cluster-final stems is complex and cannot be treated here, but see Round (in prep.).
} 
Erich R. Round

(11) Changes resulting in the loss of nominal stem-final /t/ and /t/

\begin{tabular}{|c|c|c|c|c|c|c|}
\hline & $\mathrm{t} / \mathrm{V}-\mathrm{V}$ & $\mathrm{t} / \mathrm{V}_{-}\{\#, \mathrm{C}\}$ & $\mathrm{t} / \mathrm{n}$ & $t / V_{-}$ & $\{\#, C\}$ & $t / n$ \\
\hline $\begin{array}{ll}\text { 1. } & \text { post-vocalic } \\
\text { 2. } & \text { flapping }>\text { trill } \\
& /=\{\#, C\} \\
\text { 3. } & {[\mathrm{r}]>\text { trill }[\mathrm{r}]} \\
\text { 4. } & {[\mathrm{r}]>[\mathrm{t}]}\end{array}$ & $r>r$ & $\begin{array}{l}t>r \\
r>r\end{array}$ & & $r>t$ & $\begin{array}{l}\mathrm{t}>\mathrm{r} \\
\mathrm{r}>\mathrm{r}\end{array}$ & \\
\hline \multirow[t]{2}{*}{ outcome } & $t>r$ & $t>r$ & $\begin{array}{c}\text { no } \\
\text { change }\end{array}$ & $\begin{array}{l}\text { no net } \\
\text { change }\end{array}$ & $t>r$ & $\begin{array}{c}\text { no } \\
\text { change }\end{array}$ \\
\hline & & $t>r / V_{-}$ & & & $t>r / V$ & \\
\hline
\end{tabular}

[r] apico-alveolar flap; [r] apico-postalveolar (retroflex) flap; [r] apico-alveolar trill

These changes leave behind certain traces, as presented in (12a-d). The best evidence is found in compounds given in $(12 \mathrm{c}, \mathrm{d})$, taken from modern Kayardild.

(12) Evidence in modern Tangkic for loss of final $/ \mathrm{t} /$ and $/ \mathrm{t} /$

a. Distribution within the morpheme:

\begin{tabular}{l|lll}
\hline & initial & medial & final \\
\hline $\mathrm{t}$ & yes & almost never & no \\
$\mathrm{t}$ & yes & yes & no \\
\hline
\end{tabular}

b. Relative frequencies of root-finals: [r]-finals preponderate.

c. Individual lexical evidence for $\mathrm{VrV}<* \mathrm{Vr} \# \mathrm{tV}$ or $* \mathrm{Vt} \# \mathrm{tV}$

i. muniric- 'put to one's breast' cf. munir 'breast'; -tic 'sit'

ii. „aric 'lay (egg)' cf. „ar- 'low; on the ground'; -tic- 'sit'

d. Individual lexical evidence for $\mathrm{VrV}<* \mathrm{~V} \# \mathrm{tV}$

i. malarayka 'sea-object' cf. mala 'sea'; tayka 'thing, 8

ii. walmuric- 'look up' cf. walmu 'up; high'; -tic- 'sit'

The changes to be considered next are reconstructed as having occurred after the Minkin branch splits from Tangkic, and are restricted to the latter. I also skip over a series of changes reconstructed for pre-Proto-Tangkic (see Round, in prep.) in which final segments were lost in a number of domains, summarized in (13).

\footnotetext{
${ }^{8}$ The element tayka, which in modern Tangkic languages generally means 'person, man', is reconstructed here as 'thing'. In support of tayka not originally meaning 'man': (i) the Minkin lexemes glossed as 'man' fail to include tajka, even though maku 'woman' is identical to Tangkic; (ii) Tangkic 'female' is maku, but 'male' is not tayka but *wulkal, a potential cognate of which is found in Minkin (wurar 'boy', with correspondences $k: \varnothing /$ LIQUID_ and $l: r / l$ ). In support of tayka originally meaning 'thing': (i) cf. malarayka above; (ii) tajka still carries this meaning in certain constructions in Kayardild:
}

Kayardild: Dathina riinda [jungarra dangkaa] kalaj. 'There's a [big one] flying in the east.'

[Ngaaka dangkaa] dathin? '[Which one] is that?' (pointing to a plant) 


\begin{tabular}{l|lll}
\hline Level of regularity & Domain & Segments lost & \\
\hline complete loss & word-final & labials & $\mathrm{p}, \mathrm{m}$ \\
productive, postlexical process & phrase-final & velars & $\mathrm{k}, \mathrm{n}$ \\
irregular loss, lexicalized & word-final & non-apical nasals & $\mathrm{n}, \mathrm{n}, \mathrm{g}$ \\
\hline
\end{tabular}

Note that at this stage, it will only take the deletion of phrase-final [a] to set up precisely the pattern of truncation which was proposed for Proto-Tangkic in (7b).

\section{Truncation, the Absolutive, and the Return of Word-Medial /t/}

In this final section, I detail a novel proposal for the source of the Tangkic absolutive. Entering the earliest period of truncation, the inherited, Proto-TangkicMinkin absolutive case marker was zero, i.e. absolutives were bare stems. ${ }^{9}$ As suggested above, truncation proper is set in motion by the loss of phrase-final short [a] in words of three of more syllables, with the concomitant loss, due to phonotactic constraints, of glides (cf. (5)) and of labials and velars (labials by word-level phonotactics, velars by phrase-level; see (13) above). Given this situation, it is not uncommon for entire syllables to be truncated phrase-finally. In (14) are listed what would have been the most frequently truncated syllables, together with their most frequent, leftward phonological environments.

\section{Most frequent occurrences of each type of deleted syllable}

$\begin{array}{llll}\text {-ja } & \text { after } & \text { i } & \text { in the ergative/locative case marker /-kija/ } \\ \text {-wa } & \text { after } & \text { u } & \text { in the absolutive of long stems ending in /-uwa/ } \\ \text {-.a } & \text { after } & \text { a } & \text { in the absolutive of 'north'/cirka.ja/ }{ }^{10} \\ \text {-pa } & \text { after } & \text { r } & \text { in the case marker and derivational suffix /-(n)arpa/ } \\ \text {-(y)ka } & \text { after } & \text { V } & \text { in the absolutive of long stems ending in /-(y)ka/ }\end{array}$

Soon hereafter, major syntactic changes began, restructuring biclausal structures into single clauses (Evans 1995). Prosodic restructuring would have ensued, with erstwhile multiphrasal units collapsed into single phrases. ${ }^{11}$ As a residue, some truncations now occur at particular, syntactically defined positions which are not

\footnotetext{
${ }^{9}$ Neither modern Tangkic nor Minkin preserve this reconstructed Tangkic-Minkin absolutive form (Minkin appears to append a phonological augment [-a] to consonant-final stems, cf. Evans 1980:187-8); however, considerable evidence can be mobilized in favor of reconstructing the absolutive as a bare stem (Round, in prep.).

${ }^{10}$ The lexeme cirkay a 'north' appears in the list here because in Tangkic, as in many other Australian languages, cardinal directions are employed at all scales of spatial reckoning; hence, words for 'north', 'south', 'east', and 'west' have a very high discourse frequency.

${ }^{11}$ See Fletcher et al. (2002) for the typologically marked status of Kayardild intonation in Australia. By my own observations, its distinctness is shared by Lardil; these unusual features would find a natural explanation in their having arisen diachronically through the restructuring of multi-phrasal, edge-marked units into single phrases with mobile prominence marking.
} 
final in the phrase, but medial, and when further syntactic change renders their original conditioning opaque, these phrase-medial truncations are reinterpreted simply as optional.

The next development is a reanalysis of optional truncation from a deletion of syllables to a simple alternation between long and short forms; that is, truncation originally creates shorter forms of long words, but speakers initiate a reverse process which creates longer forms for short words by augmenting them with unetymological syllables. The source of these new 'augments' is the set of most frequent, original truncated syllables listed above in (14), but with one further restriction: only those syllables are adopted which form augments homorganic with their phonological stem (that is, [-pa] is not generalized as an augment after $[\mathrm{r}])$. Examples from this new system are given in (15).

Old effects of truncation, new effects of augmentation

\begin{tabular}{|c|c|c|c|c|c|}
\hline \multirow[t]{4}{*}{ Truncation } & /tulkija/ & : & [tulki] & $<$ & [tulki-ja] \\
\hline & /kuwakuwa/ & : & [kuwaku] & $<$ & [kuwaku-wa] \\
\hline & /cirkaja/ & : & [cirka] & $<$ & [cirka-.a] \\
\hline & /malaranka/ & : & [malara] & $<$ & [malara-ıka] \\
\hline \multirow[t]{4}{*}{ Augmentation } & /piti/ & : & [piti] & $>$ & [piti-ja] \\
\hline & /maku/ & : & [maku] & $>$ & [maku-wa] \\
\hline & /wara/ & : & [wara] & $>$ & [wara-.a] \\
\hline & /yaray/ & : & [yara] & $>$ & [yara-yka] \\
\hline
\end{tabular}

Note that the only stems which now lack augments are coronal-finals (there being no labial-final stems at this point); also, other than this gap in the paradigm, the form of the augment is already identical to what will soon become the ProtoTangkic absolutive.

What I propose happened next was that the gap in the augment paradigm was filled, specifically by co-opting a truncated form of tayka 'thing' which was found in productive, left-headed nominal compounds ((6c); fn. 8 above). Note that since such compounds would necessarily comprise at least three syllables, final /-tanka/ would always be truncated to [-ta]. In compounds where the first element was attributive, the semantics of this [-ta] would be almost empty, as in (16). Generalizing from such constructions, ${ }^{12}$ this 'meaningless' [-ta] was spread to fill the gap in the augment paradigm.

\footnotetext{
${ }^{12}$ The key context would have been predicative nominal clauses such as *[maku-wa] [kalkanta]: [woman-AUGMENT] [sick(one)] 'The woman is (a) sick (one)'.
} 


\section{Pre-Proto-Tangkic Apicals and the Absolutive}

Truncation of $\mathrm{N}_{\mathrm{ATTRIBUTIVE}}+$ tajka:

\begin{tabular}{|c|c|c|c|c|}
\hline /kalkan-tayka/ & $>$ & [kalkan-ta] & 'sick (one)' & \\
\hline /campan-tanka/ & $>$ & [campan-ta] & 'hollow (one)’ & \\
\hline /tiral-tapka/ & $>$ & [tiral-ta] & ‘slippery (one)’ & with $/ \mathrm{r}+\mathrm{t} />[\mathrm{r}]$ \\
\hline /tawul-tanka/ & $>$ & [tawul-ta] & ‘new (one)' & as a relic of the \\
\hline /julmpur-tanka/ & $>$ & [julmpur-a] & 'long (one)' & changes in (11) \\
\hline /bat-tanka/ & $>$ & [ba-ta] & '(one) in the west') & exhibiting effects \\
\hline /walni:c-tanka/ & $>$ & [walyi:-ta] & 'strange (one)' & of Hamilton's genera \\
\hline /niwan-tayka/ & $>$ & [niwan-ta] & 'his (one)' & zation \\
\hline
\end{tabular}

With the adoption of [-ta] as the augment to all coronal-final stems, the full allomorphy of the non-zero absolutive was in now place. The only changes left to occur were those in which optional augment syllables became obligatory (i) after all mono- and di-syllables, a natural strategy for stress clash avoidance in a language where primary stress was predominantly word-initial, and (ii) after all consonant-final stems, making every word vowel-final.

As a final observation, we can note that this hypothesis on the origins of the Tangkic absolutive explains not only the reasons for the distinctive allomorphy of the marker, but also two further quirks of its synchronic behavior. In the first of these, the Tangkic absolutive always follows, without any semantic content, any consonant-final case suffix which otherwise would stand at the right edge of the word, i.e. it still acts as a phonological augment (Evans 1995:136-7).

The second quirk surfaces in certain Kayardild nominative NPs ${ }^{13}$ (the Kayardild nominative being the reflex of the Proto-Tangkic absolutive), namely those NPs with the form [STEM $\mathrm{N}_{\mathrm{N} \text { ATTRIBUTIVE }}$ dangka-a]. If this unit were a single word, then it would be over two syllables long and the final element should be the zero-marked -dangka $(<* \operatorname{ta\eta } k a)$, not dangka-a $(<* \operatorname{ta\eta } k a-\jmath a)$. Nevertheless, the first element is entirely uninflected, as if the whole unit really were a compound. I have only encountered such NPs where the first STEM is coronal-final. Synchronically this is hard to explain, and diachronically it only receives a coherent explanation if Tangkic absolutive [-ta] does derive from /-tanka/. In the latter case, these odd NPs in Kayardild with their zero-marked, coronal-final absolutive STEM can be seen as preserving the old situation, before [-ta] was incorporated into the augment system, ${ }^{14}$ and they do so in the one construction into which [-ta] was not extended, but in which it was original, as /tanka/.

\section{Summary}

Apical oral stops were lost from final position in nominal stems during ProtoTangkic-Minkin in a merger with trilled /r/. Apico-alveolar /t/ was also lost wordmedially, but reappears late in Proto-Tangkic in the phonological augment

\footnotetext{
${ }^{13}$ Ambiguities in the morphological status of $\mathrm{N}+/$ tanka/ also arise in Lardil (Klokeid 1976:68-72).

${ }^{14}$ Although the original construction, as one long word, would not have borne the marker ${ }_{-\imath-l} a$ at the end.
} 
Erich R. Round

syllable [-ta]. This [-ta] is in fact the last piece of an otherwise complete paradigm of augments which had recently arisen out of the partial, diachronic inversion of the Tangkic truncation rule, a paradigm which later becomes the Tangkic absolutive. The syllable [-ta] was itself derived by regular truncation from the morpheme /tayka/ 'thing', appearing in left-headed nominal compounds $\mathrm{N}_{\text {ATTRIBUTIVE }}{ }^{+/ t a n k a /, ~}$ where its semantic contribution was close to zero.

\section{References}

Blevins, Juliette. 1997. Rules in Optimality Theory: Two Case Studies. In Iggy Roca, ed., Derivations and Constraints in Phonology, 227-60. Oxford: Oxford University Press.

Evans, Nicholas. 1990. The Minkin Language of the Bourketown Region. In Geoffrey N. O'Grady and D. T. Tryon, eds., Studies in Comparative PamaNyungan, 173-207. Canberra: Pacific Linguistics.

Evans, Nicholas. 1992. Kayardild Dictionary and Thesaurus. Melbourne: University of Melbourne Linguistics Department.

Evans, Nicholas. 1995. A Grammar of Kayardild: With Historical-Comparative Notes on Tangkic. Berlin: Mouton de Gruyter.

Fletcher, Janet, Nicholas Evans, and Erich Round. 2002. Left-Edge Tonal Events in Kayardild (Australian): A Typological Perspective. In B. Bel and I. Marlien, eds., Proceedings of the First International Conference on Speech Prosody, 295-8. Provence: Laboratoire Parole et Langage.

Hale, Kenneth. 1967. Some Productive Rules in Lardil Mornington Island Syntax. Papers in Australian Linguistics, No. 2, 63-73. Canberra: Pacific Linguistics, A-11.

Hale, Kenneth. 1973. Deep-Surface Canonical Disparities in Relation to Analysis and Change: An Australian Example. In T. A. Sebeok, ed., Current Trends in Linguistics, Vol. XI: Diachronic, Areal and Typological Linguistics, 401-58. The Hague: Mouton de Gruyter.

Hamilton, Philip. 1989. Australian Phonotactics and the Internal Structure of the Place Node. M.A. thesis, University of Toronto.

Hamilton, Philip. 1996. Phonetic Constraints and Markedness in the Phonotactics of Australian Aboriginal Languages. Ph.D. diss., University of Toronto.

Keen, Sandra. 1983. Yukulta. In Robert M. W. Dixon and Barry J. Blake, eds., Handbook of Australian Languages, Vol. 3, 190-304. Amsterdam: Benjamins.

Klokeid, Terry J. 1976. Topics in Lardil Grammar. Ph.D. diss., Massachusetts Institute of Technology.

Ngakulmungan Kangka Leman (compilers). 1997. Lardil Dictionary. Gununa, Queensland: Mornington Shire Council.

Roth, W. E. 1897. Obarindi (Word List). In uncatalogued MS216, Mitchell Library, Sydney.

Round, Erich R. In preparation. A Reconstruction of Pre-Proto-Tangkic Nominal Morphology. 


\section{Pre-Proto-Tangkic Apicals and the Absolutive}

Erich R. Round

370 Temple Street, Room 204

PO Box 208366

New Haven, CT 06520-8366

erich.round@yale.edu 